\title{
SELECTION AND CHARACTERIZATION OF MEXICAN STRAINS OF BACILLUS THURZNGZENSZS ACTIVE AGAINST FOUR MAJOR LEPIDOPTERAN MAIZE PESTS
}

\author{
N. Bohorova (), A. M. Maciel ('), R. M. Brito ('), L. Aguilart (), J. E. IbarRa ( ${ }^{2}$ ) \\ \& D. HOISINGTON $\left({ }^{2}\right)$ \\ (') CIMMYT, Apdo. Postal 6-641, 06600 México, D.F., MEXICO. \\ $\left({ }^{2}\right)$ CINVESTAV-IPN, Apdo. Postal 629, 36500 Irapuato, Gto., MEXICO.
}

\begin{abstract}
In order to isolate novel delta-endotoxins from Bacillus thuringiensis Berliner, a total of 426 native isolates (in varying numbers for each pest) were screened against four major maize pests: corn earworm, Helicoverpa zea; fall armyworm, Spodoptera frugiperda; southwestern corn borer, Diatraea graridiosella, and sugarcane borer, Diatraea saccharalis. Spore-crystal complexes from the isolates were integrated into semi-artificial diets of each pest and mortality was assessed 7 days after treatment. A total of 25 isolates were selected on the basis of highest larval mortality against at least one insect species. There was no correspondence of the most toxic isolates when tested against the four different insect species. Most of the 25 selected isolates caused higher toxicities against all four pests than the standard strain HD-I, regardless of not achieving 100\% mortality in any bioassay. H. zea demonstrated the highest level of mortality (96\%) and was susceptible to the largest number of isolates (98). None of the other insect species were found susceptible at levels greater than $60 \%$. All the selected active strains were isolated from stored grain dusts (except for LBIT-167), and had bipyramidal crystals with Cry I-like proteins. Most isolates also formed an associated square (cubic) inclusion, with Cry 11-like proteins according to SDS-PAGE analysis of their parasporal bodies. The most active isolates will be subjected to further studies, in order to identify putative novel genes to be expressed in transgenic maize.
\end{abstract}

KEY-WORDS: Bacillus thuringiensis, Helicoverpa zea, Spodoptera frugiperda. Diatraea grandiosella, Diatraea saccharalis, mortality, maize.

Increased use of Bacillus thuringiensis Berliner in integrated pest management programs as bioinsecticide (Feitelson $\boldsymbol{e t}$ al., 1992) and development of transgenic plants expressing its toxins (Peferoen, 1992) have stimulated the search for more active strains of this bacterium against certain lepidopterous pests (Moar \& Trumble, 1990). Contrary to strains of pathotypes B (mosquito active) and C (coleopteran active) of $\boldsymbol{B}$. thuringiensis, pathotype $\boldsymbol{A}$ (lepidopteran active) range from highly active to almost innocuous. Variation in insecticidal activity also depends on the target species, as well as on the Cry-protein content of the parasporal bodies, acting individually or in combination (Gill et al, 1992). More than $80 \%$ of natural isolates of $\boldsymbol{B}$. thuringiensis show the typical bipyramidal parasporal body of pathotype A; however, most of these isolates show low to moderate toxicity levels against highly susceptible species (Meadows et al., 1992). This is the reason to select only the 
highly toxic strains; however, because strains show some specificity against certain lepidopteran species due to their Cry-protein content and/or combination, strain selection should be directed towards particular target pest (Dulmage, 1975).

The most important lepidopteran pests of Mesoamerican maize are: corn earworm, Helicoverpa zea (Boddie); fall armyworm, Spodoptera frugiperda (J.E. Smith); southwestern corn borer, Diatraea grandiosella (Dyar); and sugarcane borer, D. saccharalis (Fabricius). These pests can account for more than 30\% yield losses (Kumar \& Mihm,1995).The increasing costs of chemical control, and the problems related to its use, make the search for alternative control measures extremely important. B. thuringiensis has been used as bioinsecticide against these pests, with varying results (Long et al., 1961; Hensley et al., 1961; Charpenter et al., 1973; Gardner et al., 1986; Hernández, 1988;; Ali \& Young, 1993; Stone \& Sims, 1993). B. thuringiensis commercial products are usually recommended to control S. frugiperda and $\boldsymbol{H}$. zea, but not D. grandiosella and D. saccharalis. However, all four species are recognized for their moderate to low susceptibility to these products (Krieg \& Langenbruch, 1981). Furthermore, the feeding habits of these insects, make them difficult to intoxicate with the sprayed products. For this reason, much effort is being directed towards the development of transgenic maize, expressing one or more B. thuringiensis toxins (Koziel et al., 1993).

As part of a project to develop transgenic maize for management of lepidopteran pest populations, the International Maize and Wheat Improvement Center (CIMMYT) has conducted a selection of Mexican B. thuringiensis isolates collected by the Center for Research and Advanced Studies (CINVESTAV). Selected isolates may provide coding genes for specific and active toxins. This report presents a selection of toxic native isolates of B. thuringiensis from a total of 426 strains, against the four most important lepidopteran pests of maize in Mesoamerica, as well as a preliminary characterization of the selected isolates.

\section{MATERIAL AND METHODS}

\section{BACTERIAL STRAINS}

In a nationwide isolation program of Mexican B. thuringiensis strains, pasteurized samples of soil, grain dust, and insects were plated on nutrient agar and single colonies containing inclusion bodies were isolated and grown for further study (Sneath, 1986). Stocks were registered, freeze-dried and kept at $-20^{\circ} \mathrm{C}$ at the CINVESTAV's stock collection.

\section{CULTURE CONDITIONS AND SPORE-CRYSTAL FORMULATION}

Cultures of 426 isolates were grown in PMB medium $(10 \mathrm{~g}$ peptonized milk, $10 \mathrm{~g}$ dextrose; $2 \mathrm{~g}$ yeast extract; $0.3 \mathrm{~g} \mathrm{MgSO} .7 \mathrm{H}_{2} \mathrm{O} ; 20 \mathrm{mg} \mathrm{FeSO}{ }_{4} 7 \mathrm{H}_{2} \mathrm{O} ; 20 \mathrm{mg} \mathrm{ZnSO}_{4} .7 \mathrm{H}_{2} \mathrm{O}$; $20 \mathrm{mg} \mathrm{MnSO}_{4}$, in 11 destilled water; $\mathrm{pH}$ 7.2-7.5), incubated at $30^{\circ} \mathrm{C}$ under agitation (340 rpm) until complete autolysis was achieved. The spore-crystal complexes were harvested by centrifugation at $10,000 \mathrm{rpm}$ for $10 \mathrm{~min}$ at $4^{\circ} \mathrm{C}$. Spores, parasporal bodies, and cell debris were washed three times in distilled water by centrifugation $(10 \mathrm{~min}$, $10,000 \mathrm{rpm})$. Pellets of spore-crystal complexes were freeze-dried and stored at $-20^{\circ} \mathrm{C}$ until bioassayed. 


\section{INSECT REARING AND BIOASSAY}

Larvae of H. zea, S.frugiperda, D. grandiosella, D. saccharalis, were obtained from colonies maintained on artificial diets at $27^{\circ} \mathrm{C}$ with a photoperiod of $16: 8 \mathrm{~h}$ (light:dark).

Artificial diets, prepared as described by Mihm (1982, 1983a, 1983b), were used for all tests. Each strain's freeze-dried spore-crystal complex was diluted in water, and mixed with a vortex mixer for $1 \mathrm{~min}$., sonicated, and added to the diet at the rate of $50 \mu \mathrm{g}$ per g diet. The same procedure was followed with the standard strain HD- 1. One hundred ml of the diet was mixed well with spore-crystal and poured into each well of a 32-well microtiter plate (Oliver). The diet was allowed to solidify and a single larva (one-day old larvae of S.frugiperda, D. grandiosella, and D. saccharalis and 2-day old larvae of H. zea) was added to each well. Microtiter plates were covered with polyester film lidding material (Oliver), and incubated in a growth chamber at $27^{\circ} \mathrm{C}$ and a photoperiod of $16: 8 \mathrm{~h}$ (light:dark). Thirty-two insects were evaluated per strain and each treatment was replicated at least three times. Larval mortality was assessed afier 7 days. Mortality of the control larvae reared on a toxin-free diet and under the same conditions was recorded and used to correct the test mortality with Abbott's formula (Abbott, 1925).

\section{PARASPORAL BODY MORPHOLOGY}

In order to establish the crystal morphological type of the selected isolates, wet mounts of both intact and autolyzed sporangia of each isolate were observed under phase contrast microscopy. The three typical morphologies (bipyramidal, spherical-amorphous and flatsquare) were discriminated. Inclusions associated with bipyramidal crystals were also identified. In order to try to correlate activity with crystal proportions, a classification of crystals and inclusions according to their size was developed as a means of discrimination between isolates.

\section{SDS-PAGE ELECTROPHORESIS}

Protein composition of the selected isolate's spore-crystal complexes was determined using SDS-PAGE essentially as described by Laemli and Favre (1973), with a 3\% stacking gel and $10 \%$ running gel in a Bio-Rad mini-protean II cell slab vertical gel apparatus at $50 \mathrm{~V}$ for $15 \mathrm{~min}$ and $100 \mathrm{~V}$ for 1.5 hour. Gels were stained with Coomassie blue. The molecular masses of the putative parasporal body proteins were estimated by comparaison with those of the following proteins subjected to SDS-PAGE: carbonic anhydrase $(29 \mathrm{kDa})$, ovalbumin $(45 \mathrm{kDa})$, bovine serum albumin $(66.2 \mathrm{kDa})$, phosphorylase $\mathrm{B}(97.4 \mathrm{kDa})$, B-galactosidase $(116.25 \mathrm{kDa})$, and myosin $(205 \mathrm{kDa})$.

\section{RESULTS}

\section{STRAIN ISOLATION}

A total of 426 isolates (isolated from 522 source samples) was included in this study. Stored grain dusts were the most abundant and diverse source samples (82\%), while soil and insect samples provided a smaller proportion of the total (11 and 7\%, respectively). A majority of the isolates $(84 \%)$ showed the presence of bipyramidal crystals, similar to those typical of isolates active against Lepidoptera (pathotype A). A few isolates exhibited crystals similar to those active against mosquitoes $(8 \%)$ and Coleoptera $(3 \%)$. The remaining 5\% showed atypical crystal morphologies. 
TABLE 1

Summary of different features shown by each of the more toxic Mexican Bacillus thuringiensis isolates, tested against first instar larvae of $H$. zea, $S$. frugiperda, D. grandiosella, and D. saccharalis

\begin{tabular}{|c|c|c|c|c|}
\hline \multirow[b]{2}{*}{ LBIT-Isolate } & \multicolumn{4}{|c|}{ Attribute of the isolate } \\
\hline & Source & BIP. & INCL. & PROT. \\
\hline 13 & Maize & SML & SML & $\mathbf{I} / \mathrm{II}$ \\
\hline 27 & Sorghum & SML & SML & I/II \\
\hline 29 & Maize & SML & SML & I/II \\
\hline 114 & Beans & LRG & ABS & I \\
\hline 124 & Maize & LRG & SML & $I / I I$ \\
\hline 128 & Maize & NRM & SML. & $\mathrm{I} / \mathrm{II}$ \\
\hline 135 & Maize & SML & SML & $\mathrm{I} / \mathrm{II}$ \\
\hline 139 & Maize & LRG & $\mathrm{ABS}$ & I \\
\hline 144 & Wheat & NRM & SML & I/II \\
\hline 149 & Sorghum & LRG & ABS & I \\
\hline 151 & Wheat & NRM & ABS & I \\
\hline 167 & (Soil) & NRM & SML & I/II \\
\hline 174 & Maize & NRM & SML & I/II \\
\hline 175 & Maize & SML & ABS & I \\
\hline 178 & Sorghum & LRG & SML & $\mathrm{I} / \mathrm{II}$ \\
\hline 181 & Maize & NRM & SML & III \\
\hline 193 & Maize & NRM & ABS & I \\
\hline 199 & Rice & NRM & SML & I/II \\
\hline 226 & Sorghum & LRG & ABS & I \\
\hline 227 & Sorghum & NRM & SML & $\mathrm{I} / \mathrm{II}$ \\
\hline 236 & Beans & NRM & SML & $\mathrm{I} / \mathrm{II}$ \\
\hline 259 & Sorghum & LRG & SML & $\mathbf{I} / \mathbf{I I}$ \\
\hline 290 & Sorghum & NRM & ABS & I \\
\hline 301 & Beans & NRM & LRG & $\mathrm{I} / \mathrm{II}$ \\
\hline 437 & Maize & SML & ABS & I \\
\hline
\end{tabular}

Source : Stored grain dust the strain was isolated from; BIP.: Size of the isolate's bipyramidal crystal (LRG: Large, NRM: Normal, SML: Small); INCL.: Presence and size of the cubic inclusion, associated to the bipyramidal crystal (ABS: Absent); PROT Presence of putative Cry I/Cry II proteins.

Almost all the 25 most toxic isolates tested against the four lepidopteran maize pests were isolated from dusts of stored maize, sorghum, beans, and wheat. Only isolate LBIT-167 was isolated from soil (table 1).

\section{BIOASSAYS}

Figure 1 shows the mortality distribution of a total of 352 isolates tested against D. grandiosella. Almost $99 \%$ of the isolates caused mortalities lower than $50 \%$, with only 4 isolates inducing mortalities between 50 and $80 \%$. No isolate caused higher mortalities. Similarly, all the 337 isolates tested against D. saccharulis exhibited mortalities lower than $50 \%$ (fig. 2). When a total of 156 isolates was tested against S. frugiperda, only 6 (4\%) induced mortalities between $50 \%$ and $70 \%$. No isolate caused mortalities greater than $70 \%$ (fig. 3). A different distribution was observed when 96 isolates were bioassayed against $H$. $z e a$, as only $27 \%$ of the isolates tested exhibited a mortality lower than $50 \%$. The remaining $73 \%$ of the isolates caused mortalities between 50 and $99 \%$; however, no isolate showed $100 \%$ mortality under the conditions tested (fig. 4). 


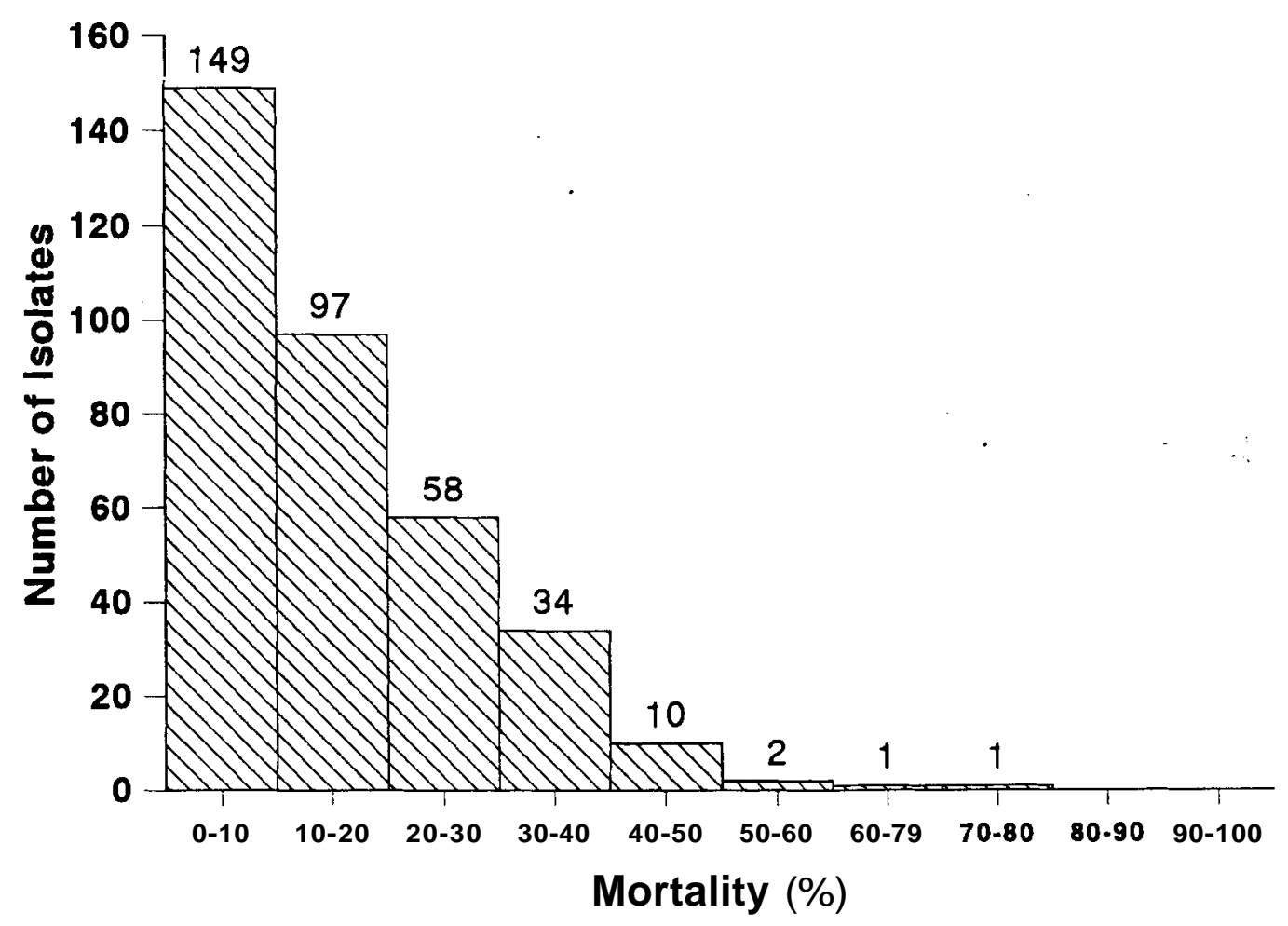

Fig. I. Mortality distribution of spore-crystal complexes of Bacillus thuringiensis native isolates against D. grandiosella first instar larvae.

Table 2 shows the mortality levels obtained by the most active isolates, when tested against the four lepidopteran pests. These 25 isolates were selected on the bases of highest larval mortality against at least one insect species. Isolates LBIT-437, 139 and 259 caused the highest toxicity against D. grandiosella, while isolates LBIT-13, 236 and 29 induced the highest mortalities against D. saccharalis. On the other hand, isolates LBIT-193 and 27 caused the highest mortalities against S. frugiperda and isolates LBIT-227, 199, 144 and 149 induced the highest toxicities against $\mathrm{H}$. $z \boldsymbol{e} \boldsymbol{a}$. There was no correspondence of the most toxic isolates when tested against different insect species. An attempt to relate the toxicity levels of each strain between different insect species was made by regression analysis (data not shown); however, no significant regression was obtained, except when mortality levels recorded for D. grandiosella were related to those of the remaining species. Interestingly, the regression was negative.

When the performance of the native isolates was compared with that of the standard HD-I. 16,, 20, and 17 native isolates caused higher mortality than the standard, when tested against H. zea, S. frugiperda. D. grandiosella, and D. saccharalis, respectively (table 2).

\section{CRYSTAL MORPHOLOGY}

A close inspection of the parasporal bodies formed by the 25 selected isolates under phase contrast microscopy showed that all the isolates exhibit a bipyramidal crystal and 16 


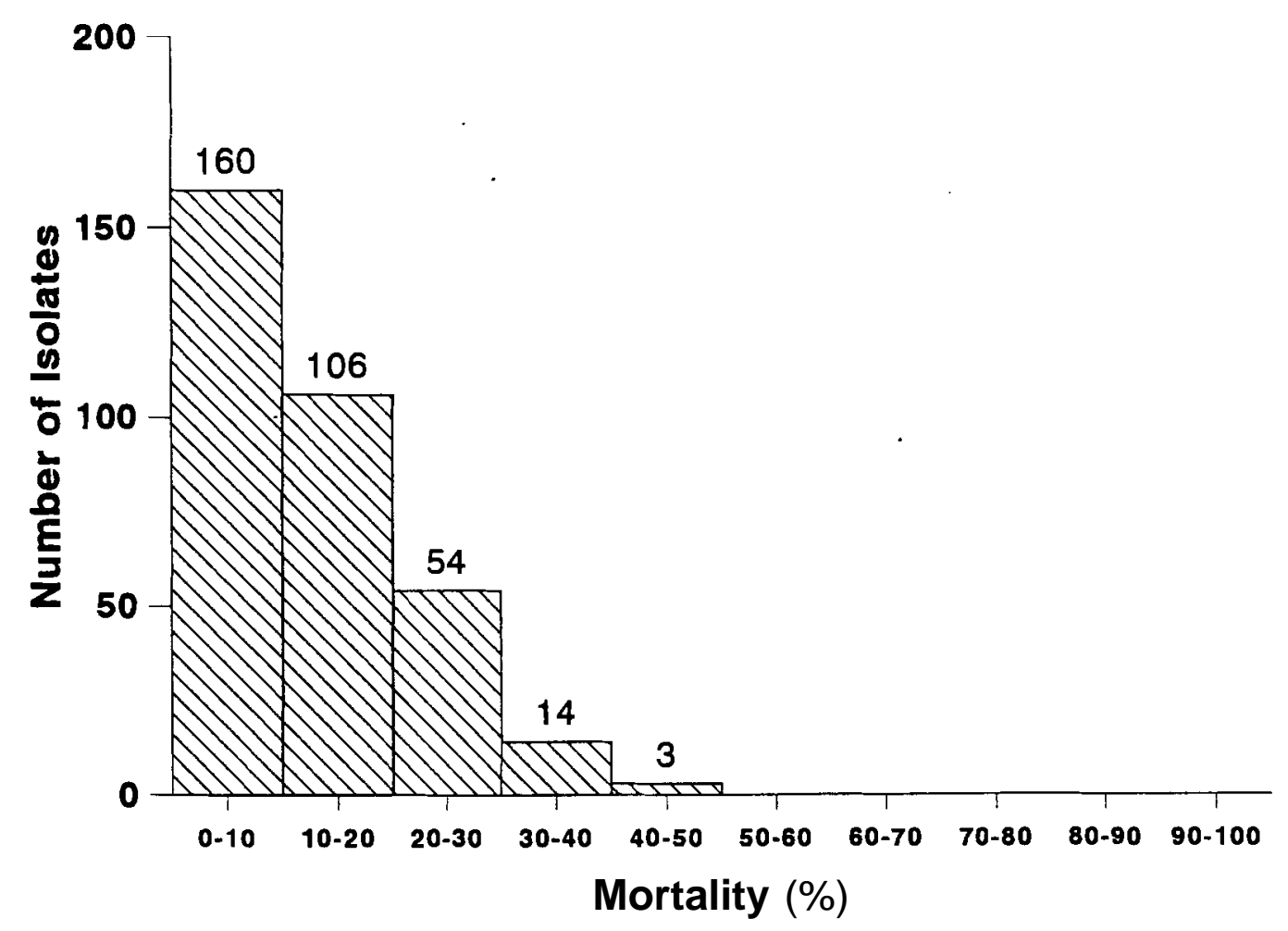

Fig. 2. Mortality distribution of spore-crystal complexes of Bacillus thuringiensis native isolates against D. saccharalis first instar larvae.

revealed a square (or cubic) inclusion along the main crystal. Bipyramidal crystals varied significantly in size and were arbitrarily classified as: small, normal and large, if they were smaller, equal or larger than $1 \mathrm{pm}$, respectively (table 1). When present, the cubic inclusion was always ca. $0.5 \mu \mathrm{m}$ large, except for isolate LBIT-301, which showed a large cuboidal inclusion, even larger than the bipyramidal crystal.

Twelve isolates showed normal size bipyramidal crystals while 6 and 7 isolates exhibited smaller and larger crystals, respectively. The most frequent combination was a normal size bipyramidal crystal with a small inclusion; however, most of the isolates which produce significantly large bipyramidal crystals were not associated with cubic inclusions. When crystal morphology of the five most active isolates against each of the maize pests was compared. no specific morphology was associated to the activity, except that 14 out of the 19 isolates show the presence of cubic inclusions.

\section{PEPTIDE CONTENT}

When trying to correlate the diversity of crystal proteins with the toxicity levels found in the screening, SDS-PAGE analysis of the parasporal bodies produced by the 25 selecter isolates revealed two basic patterns. One included one to three proteins in the range of 125 


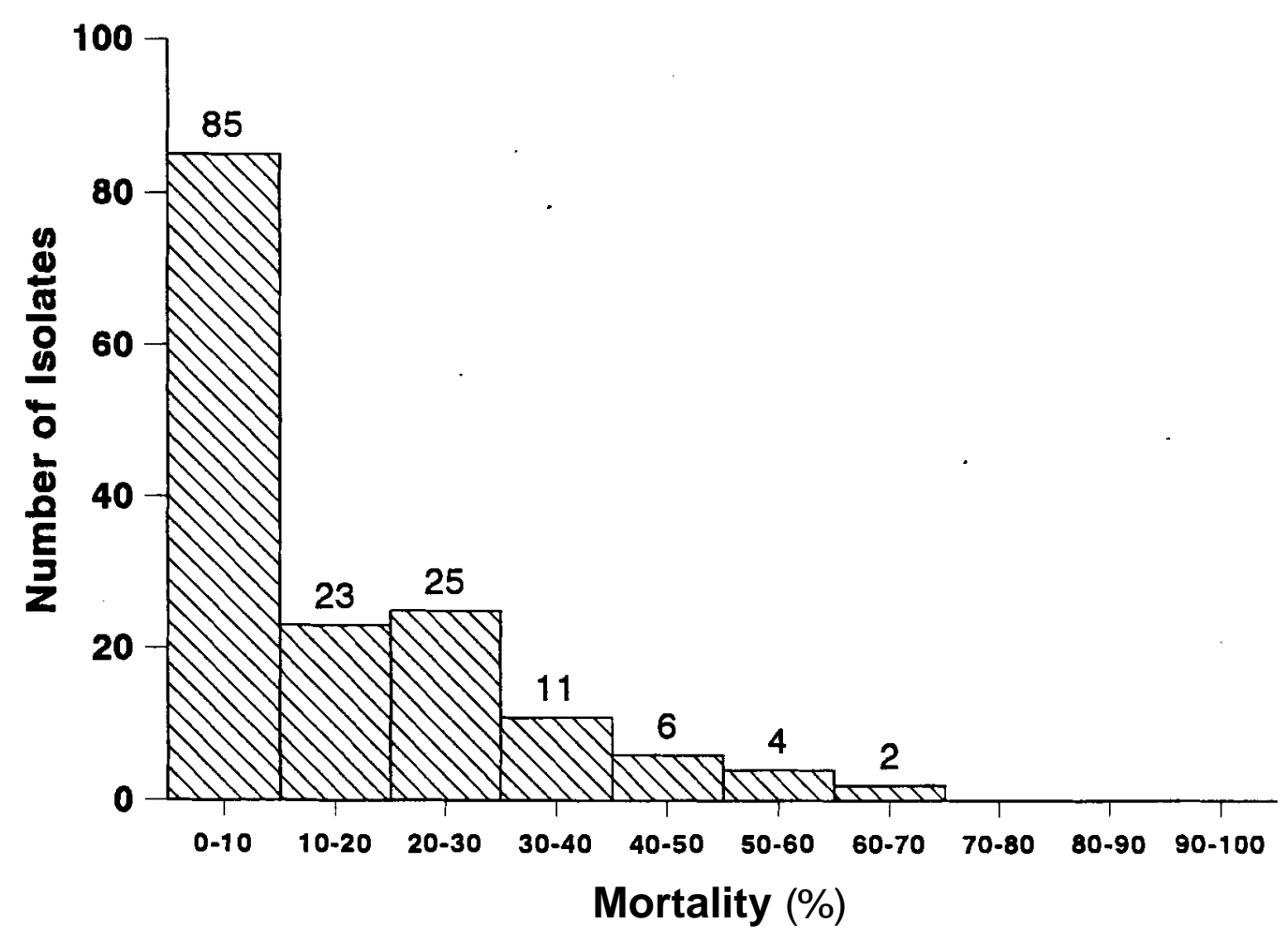

Fig. 3. Mortality distribution of spore-crystal complexes of Bacillus thuringiensis native isolates against $\mathbf{S}$. frugiperda first instar larvae.

to $140 \mathrm{kDa}$, and a second included these proteins along with one or two proteins in the range of 60 to $65 \mathrm{kDa}$ (fig. 5, table 1). According only to the molecular size and host range, the larger proteins may be related to the Cry I protoxins, while the smaller proteins may be related to the Cry II protoxins (Hofte \& Whiteley, 1989). Most of the active strains show a combination of both types of protoxins; however, from the five most active strains against D. grandiosella, three show only Cry I-like protoxins.

\section{DISCUSSION}

Isolation of native B.thuringiensis strains from the total processed samples was higher than $80 \%$, and higher than $86 \%$ from stored grain dusts. These results indicate the relative abundance of wild strains. All native isolates were tested in varying numbers against the four major lepidopteran maize pests and, regardless their higher proportion, an overwhelming majority of the selected isolates was obtained from grain dusts. Interestingly, in spite of maize dust being a major source of selected isolates (44\%), the most active strains were isolated mostly from other sources. However, sorghum dust was also a major source of selected strains $(28 \%)$. and it should be considered as an alternative host for at least some 


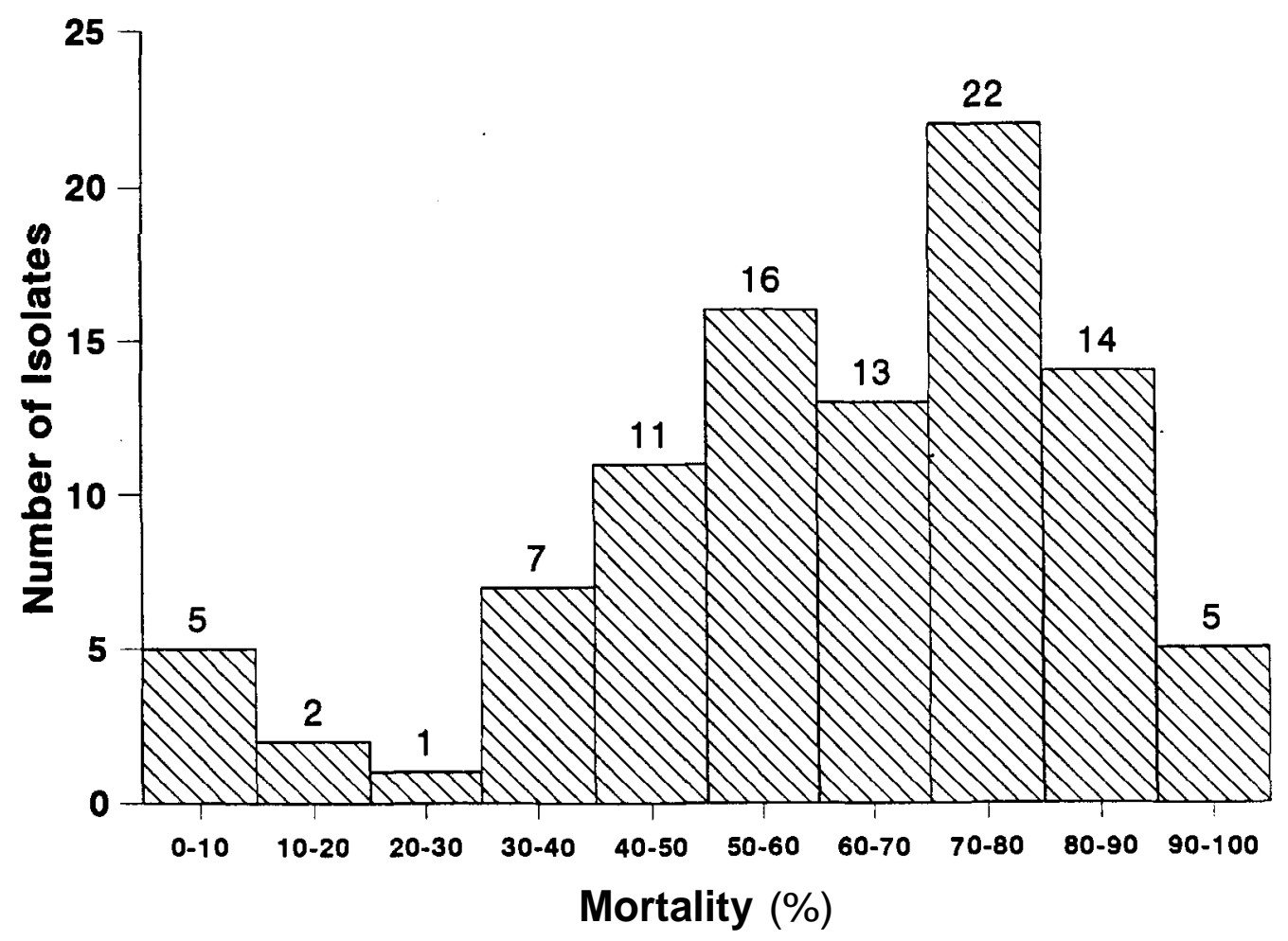

Fig. 4. Mortality distribution of spore-crystal complexes of Bacillus rhuringiensis native isolates against $\mathrm{H}$. zea first instar larvae.

of the studied pests. In spite of this, there are previous reports where B.thuringiensis strains, isolated from grain dusts, show high activity against insects totally unrelated to grain (López-Meza \& Ibarra, 1995).

Most of the selected isolates induced mortality levels higher than those induced by the standard HD-I. This clearly indicates their potential as a source of genes expressing active toxins. It is important to note that the dose tested was considerably high and the levels of toxicity were lower than those obtained against other highly susceptible insect species (i.e. the tobacco hornworm, Manduca sexta L.) (Schesser et al., 1977); however, toxicity should be measured not only in terms of mortality, but also in terms of development reduction. This development effect has been recorded previously (De León \& Ibarra, 1995), and it is possible that pest damage can be significantly reduced even when mortality is low (Arpaia \& Ricchiuto, 1993; Schesser et al., 1977). This effect was obvious in our bioassays against the four pests. as all the selected isolates (including HD-I) induced a significant size reduction in the larvae fed treated diet when compared with controls (data not shown). In other words, the use of moderately toxic proteins in transgenic maize is feasible, and it might be even helpful in the management of resistance development (McGaughey \& Whalon, 1992).

According to the bioassays, H.zea is the most susceptible species of all four. This is clearly indicated not only by the highest mortalities obtained in the bioassays but also in the 
TABLE 2

Mortality achieved by selected Mexican Bacillus thuringiensis isolates, tested against first instar larvae of $H$. zea, S. frugiperda, D. grandiosella, and D. saccharalis

\begin{tabular}{|c|c|c|c|c|}
\hline \multirow[b]{2}{*}{ LBIT-Isolate } & \multicolumn{4}{|c|}{$\%$ Larval Mortality per Insect Species } \\
\hline & H. zea & S. frugiperda & D. grandiosella & D. saccharalis \\
\hline 13 & 53.5 & 20.1 & 18.8 & 40.9 \\
\hline 27 & 56.4 & 62.2 & 20 & 17.2 \\
\hline 29 & 74.5 & 4.7 & 22.6 & 34.3 \\
\hline 114 & 43.3 & 3.2 & 48.3 & 1.6 \\
\hline 124 & 69.9 & 4.8 & 31.7 & 31.7 \\
\hline 128 & 71.8 & 6.6 & 53.3 & 18.3 \\
\hline 135 & 70.7 & 38.9 & 19.7 & 16.9 \\
\hline 139 & 42.9 & 28.9 & 60.7 & 1.7 \\
\hline 144 & 92.3 & 35.6 & 41.9 & 15.6 \\
\hline 149 & 92.3 & 40.9 & 22.6 & 9.4 \\
\hline 151 & 80.6 & 47.4 & 29 & 15.6 \\
\hline 167 & 88.8 & 16.7 & 38.7 & 6.3 \\
\hline 174 & 81.3 & 41.3 & 12.9 & 26.7 \\
\hline 175 & 84.5 & 43.4 & 19.4 & 9.4 \\
\hline 178 & 92.5 & 8.4 & 9.7 & 0 \\
\hline 181 & 84.5 & 52.3 & 25.8 & 12.5 \\
\hline 193 & 54.1 & 65.2 & 3.2 & 15.6 \\
\hline 199 & 93.4 & 25.7 & 16.1 & 3.2 \\
\hline 226 & - & 50.4 & 23.3 & 20 \\
\hline 227 & 96.6 & 23.9 & 6.3 & 33.3 \\
\hline 236 & - & 8.4 & 12.5 & 37.6 \\
\hline 259 & 46.6 & 3.9 & 56.3 & 3.2 \\
\hline 290 & 89.9 & 0.7 & 18.8 & 3.3 \\
\hline 301 & - & 53.8 & 29 & 3.3 \\
\hline 437 & - & - & 71 & - \\
\hline HD-I & 54.6 & 10.2 & 13.7 & 6.1 \\
\hline
\end{tabular}

mortality distribution of all the tested strains, as most caused mortalities of $\mathrm{H}$. zea higher than $50 \%$. The remaining three species are much less susceptible and they have been always considered as "recalcitrant" species (Krieg \& Langenbruch, 1981). S. frugiperda is a moderately susceptible species; however, B. thuringiensis has been rarely recommended to control either D. grandiosella or D. saccharalis (Metcalf \& Metcalf, 1993; Meister, 1986). These previous observations have been confirmed by our study, as none of the tested isolates induced mortalities higher than 50\% against D. saccharalis and only 4 caused mortalities higher than $50 \%$ against D. grandiosella. Once this first screening of isolates is over, proper estimation of the $\mathrm{LC}_{50}$ 's using purified toxins is essential to establish toxicity levels from those isolates which caused the highest mortalities on each insect pest. However, these results are sufficient to initiate the identification of toxin-encoding genes from the most active isolates.

It should be noticed that, due to the fact that no correspondence was observed of the most active strains among the different pests, high specificity between the toxins and membrane receptors of each species can be expected. This becomes a problem, if the final goal aims toward the control of these pests by the expression of toxins in the plant tissues. Under the attack of several species, a proper control level might be achieved only if all the 


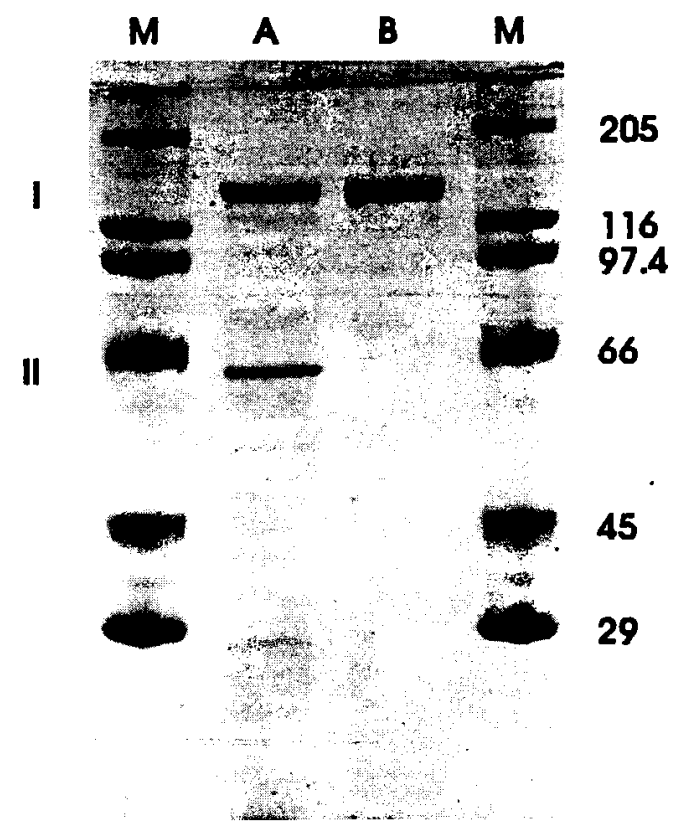

Fig. 5. SDS-polyacrylarnide gel showing the two basic patterns obtained from the 25 selected native isolates. Lane A: pattern oftwo types of Cry proteins; Lane B: pattern of one type of Cry proteins. I: putative Cry I proteins; II: putative Cry II proteins; M: molecular weight markers (size is in $\mathrm{kDa}$ ).

different active toxins are expressed, which is impractical from the technical point of view. Furthermore, due to the moderate levels of toxicity shown against the Diatraea spp., high expression levels might be required to achieve optimum control. Previous problems with appropriate expression levels of B. thuringiensis toxins in plants were successfully overcome by the synthesis of genes, changing the original prokaryotic codon usage by an eukaryotic one (Koziel et al., 1993). This solution might be applicable to the toxins reported here.

All the selected isolates form a bipyramidal crystal, typical of the pathotype A (active against Lepidoptera) (Krieg et al., 1987). Also there was no correlation between toxicity levels and crystal size and/or the presence of the cubic inclusion (Donovan et al.. 1988). It is known that the activity is rather related to a combination of the insect's ability to dissolve and partially digest the crystal proteins, as well as the affinity of the deltaendotoxins to membrane receptors and their ability to create membrane pores (Gill et al., 1992). However, partial characterization of the crystal (including the peptide content) is helpful and provides useful information about each isolate. Based on molecular weights, peptide contents indicated the presence of putative Cry I proteins in the bipyramidal crystals, and of putative Cry II proteins in the cubic inclusions (when they were present). Proper identification of these proteins would require Western blot analysis, using specific (in some cases, monoclonal) antibodies. It is worth noticing that the preliminary characterization of the 25 selected isolates showed typical attributes of strains within the pathotype A in all isolates except one. The exception was isolate LBIT-437, whose bipyramidal crystal was rather narrow and its major protein content included bands of lower molecular weight 
peptides than that reported for Cy I proteins. This isolate is currently being subjected to a thorough characterization, as it was the most active isolate against D. grandiosella and might produce a novel toxin, according to the unusual molecular weight.

Additionally, the most active isolates against each insect pest will be subjected to a thorough characterization, which will include serotyping, ultrastructural morphology of the parasporal body, plasmid pattern, differentiation of all cy proteins, cloning and sequencing of the genes expressing the most active Cy proteins, etc. This information will provide the basis to proceed towards the successful development of transgenic maize, resistant to the attack of these major maize pests.

\section{RÉSUMÉ}

Selection et caractérisation d'isolats mexicains de Bacillus thuringiensis actifs contre quatre Lépidoptères majeurs du maïs

Les 426 souches de Bacillus thuringiensis Berliner isolées ont été testées sur quatre ravageurs importants du mais, Helicoverpa zea, Spodoptera frugiperda, Diatraea grandiosella, Diatraea saccharalis dans le but d'identifier de nouvelles delta endotoxines. Le complexe spore-cristal obtenu a partir de chacun des isolats a été incorporé dans un milieu nutritif artificiel pour insecte et la mortalité a été relevée apres sept jours de traitements. Vingt-cinq isolats ont été sélectionnés sur la base d'une toxicité élevée sur les larves d'au moins une espèce. Aucun des isolats actifs ne s'est révélé actif à la fois contre les quatre espèces d'insectes étudiées. La plupart des 25 isolats sélectionnés ont montré une toxicité supérieure à celle de la souche de reférence $\mathrm{HD}-1$, que la mortalité ait atteint ou non $100 \%$. H. zea s'est révélée être l'espèce la plus sensible ( $96 \%$ de mortalité) au plus grand nombre d'isolats (98). Aucune des trois autre especes n'a montré plus de $60 \%$ mortalité. Toutes les souches actives ont été isolées à partir de poussières de graines stockées (excepté l'isolat LBIT- 167) et produisaient des cristaux bipyramidaux. L'analyse du contenu protéique des cristaux en gel de polyacrylamide-SDS a montre que les cristaux bipyramidaux contenaient des protéines de type Cryl et que les cristaux cubiques associés produits par la plupart des isolats contenaient des protéines de type CryII. Les souches les plus actives seront analysées de façon plus approfondie afin de détecter la presence potentielle de nouveaux gènes pouvant être exprimés chez les maïs transgéniques.

Received : 2 October 1995 : Accepted : 7 August 1996.

\section{REFERENCES}

Abbott, W. S. - 1925. A method of computing the effectiveness of an insecticide. - J. Econ. Entomol., 18, 265-267.

Ali, A. \& Young, S. Y. - 1993. Bacillus thuringiensis var. kurstaki activity against larvae of Helicoverpa zea and Heliothis virescens (Lepidoptera: Noctuidae) on cotton. - J. Econ. Entomol., 86, 1064-1068.

Arpaia, S. \& Ricchiuto, B. - 1993. Effects of Bacillus thuringiensis toxin extracts on feeding behavior and development of Colorado potato beetle (Coleoptera: Chrysomelidae) larvae. Environ. Entomol., 22, 334-338.

Charpenter, J. L., Jackson, R. D. \& McCormick, W. J. - 1973. Sugarcane Borer: Control by delta-endotoxin of Bacillus thuringiensis, HD-I, in Field Tests. - J. Econ. Entomol., 66, 249-251.

De León, T, \& Ibarra, J. E. - 1995. An Alternate bioassay technique to measure the activity of Cry III proteins of Bacillus thuringiensis. - J. Econ. Entomol., 88, 1596-1601.

Donovan, P. W., Dankocsik, C. C., Gilbert, M. P., Gawron-Burke, M. C., Groat, R. G., \& Carton, B. C. - 1988. Amino acid sequence and entomocidal activity of the P2 crystal protein. J. Biol. Chem., 263, 561-567. 
Dulmage, T. H. - 1975. The Standardization of formulations of the delta-endotoxins produced by Bacillus thuringiensis. - J. Invertebr. Pathol., 25, 279-281.

Feitelson, S. J., Payne, J. \& Kim, L. - 1992. Bacillus thuringiensis = Insects and Beyond. Biotechnology, 10, 271-275.

Gardner, W. A., Pendley, A. F. \& Storey, G. K. - 1986. Interactions between Bacillus thuringiensis and its beta-exotoxin in fall armyworm (Lepidoptera: Noctuidae) neonate larvae. - Fla. Entomol., 69, 531-536.

Gill, S. S., Cowles, E. A. \& Pietrantonio, P. V. - 1992. The mode of action of Bacillus thuringiensis endotoxins. - Annu. Rev. Entomol., 37, 615-36.

Hensley, S. D., McCormick, W. J., Long, W. H. \& Concienne, E. J. - 1961. Field tests with new insecticides for control of the sugarcane borer in Louisiana in 1959. - J. Econ. Entomol., 54, 1153-1154.

Hernández, J. L. - 1988. Evaluation de la toxicité de Bacillus thuringiensis sur Spodoptern frugiperda. - Entomophaga, 33, 163-171.

Hofte, H. \& Whiteley H. R. - 1989. Insecticidal crystal proteins of Bacillus thuringiensis. Microbiol. Rev., 53, 242-255.

Koziel, M. G., Beland, G. L., Bowman, C., Carozzi, N. B., Crenshaw, R., Crossland, L., Dawson, J., Desai, N, Hill, M., Kadwell, S., Launis,K., Lewis, K., Maddox, D., McPherson, K., Meghji, M., Merlin, E., Rhodes, R., Warren, G. W., Wright, M., \& Evola, S. - 1993. Field performance of elite transgenic maize plants expressing an insecticidal protein derived from Bacillus thuringiensis. - Biotechnology, 11, 194-200.

Krieg, A. \& Langenbruch, G. A. - 1981. Susceptibility of arthropod species to Bacillus thuringiensis In: Microbial Control of Pests and Plant Diseases 1970-1980 (H. D. Burges, ed.) Academic Press, New York, 837-896.

Krieg, A, Schnetter, W, Huger, A. M. \& Langenbruch, G. A. - 1987. Bacillus thuringiensis subsp. tenebrionis, strain BI 256-82 : a third pathotype within the H-Serotype 8a8b. - System. Appl. Microbial., 9, 138-141.

Kumar, H. \& Mihm, J. A. - 1995. Antibiosis and tolerance to fall armyworm, Spodoptern frugiperda (J. E. Smith), southwestern corn borer, Diatraea grnndiosella Dyar and sugarcane borer. Diatraea saccharalis Fabricius in selected maize hybrids and varieties. - Maydica, 40, 245-251.

Laemmli, U. K. \& Favre, M. - 1973. Maturation of the head of bacteriophage T4. I. DNA packing agents. - J. Mol. Biol., 80, 575-599.

Long, W. B., Hensley, D., Concienne, E. J. \& McCormick, W. J. - 1961. Field tests with new insecticides for sugarcane borer control in Louisiana in 1960. - J. Econ. Entomol., 54, 1155-1156.

López-Meza, J. E., Federici, B. A., Poehner, W. J., Martinez-Castillo, A.M. \& Ibarra, J. E. - 1995. Highly mosquitocidal isolates of Bacillus thuringiensis subspecies kenyae and entomocidus from Mexico. - Biochem. System. Ecol., 23, 461-468.

McGaughey, W. H. \& Whalon, M. E. - 1992. Managing insect resistance to Bacillus thuringiensis toxins. - Science. 258, 1451-1455.

Meadows, M. P., Ellis, D. J., Butt, J. Jarret, P. \& Burges, D. - 1992. Distribution, frequency, and diversity of Bacillus thuringiensis in an animal feed mill. - Appl. Environ. Microbiol. 58. 1344-1350.

Meister, R. T. - 1986. Insecticide Product Guide. 1986. - Ag Consultant and Fieldman. Meister Publishing Co. Willoughby, OH. 250 pp

Metcalf, R. L. \& Metcalf, R. A. - 1993. Destructive and Useful Insects. Their Habits and Control. 5th Ed. - McGraw-Hill, Inc. New York, 9. 11-9, 14, 9.31-9.33, 9.59-9.60.

Mihm, J. - 1982. Techniques for efficient mass rearing and infestation in screening for host plant resistance to corn earworm Heliothis zea. - CIMMYT, Mexico.

Mihm, J. - 1983a. Techniques for efficient mass rearing and infestation off all armyworm, Spodoptern frugiperda J. W. Smith for host plant resistance studies. - CIMMYT. Mexico. 
Mihm, J. - 1983b. Techniques for efficient mass rearing and infestation in screening for host plant resistance to Diatraea sp. maize stem borers. - CIMMYT, Mexico.

Moar, W. J. \& Trumble, J. T. - 1990. Comparative toxicity of five Bacillus thuringiensis strains and formulations against Spodoptera exigua (Lepidoptera: Noctuidae). - Fla. Entomol., 73, 195-197.

Peferoen, M. - 1992. Engineering of insect-resistant plants with Bacillus thuringiensis crystal protein genes. - Plant Genetic Manipulation for Crop Protection, 7, 135-153.

Schesser, J. H., Kramer, K. J., \& Bulla, Jr., L. A. - 1977. Bioassay for homogenous parasporal crystal of Bacillus thuringiensis using the tobacco hornworm, Manduca sexta. - Appl. Environ. Microbiol., 33, 878-880.

Sneath, P. H. A. - 1986. Endospore-forming Gram-Positive Rods and Cocci. In : J.H. Holt. Bergey's Manual of Systematic Bacteriology, Vol. 2. - Williams \& Wilkins., London. 1104-1207.

Stone, B. T. \& Sims, S. R. - 1993. Geographic susceptibility of Heliothis virescens and Helicoverpa zea (Lepidoptera: Noctuidae) to Bacillus thuringiensis. - J. Econ. Entomol., 86, 989-994. 